
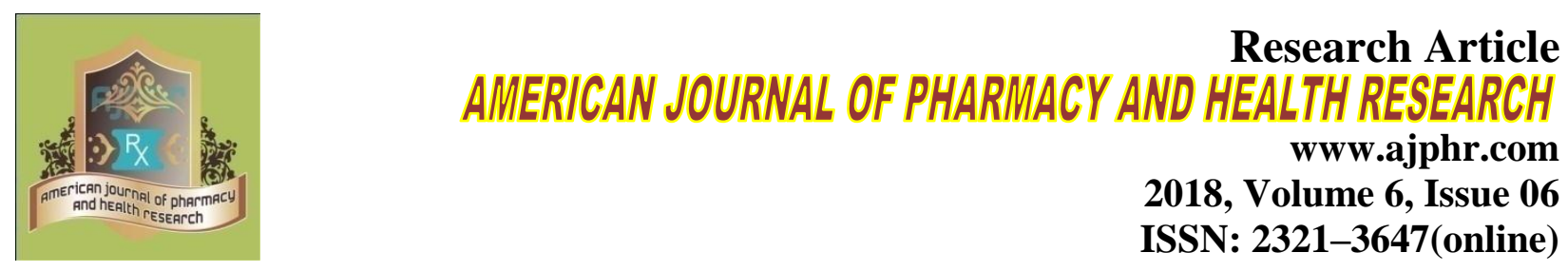

\title{
RP-HPLC Method Development and Validation for Simultaneous Estimation of Hydrocortisone and Acyclovir in Pharmaceutical dosage forms.
}

\author{
Ramavath Mohanbabu Naik ${ }^{*}$, Syed Ahmed ${ }^{1}$, G. Naveen kumar Reddy ${ }^{2}$ \\ 1.Department of Pharmaceutical Analysis and Quality Assurance, Gland institute of \\ pharmaceutical science \\ 2.Department of Pharmacognosy, Surabhi Dayakar Rao college of Pharmacy
}

\begin{abstract}
The Chromatographic condition were successfully developed for the separation of Acyclovir and Hydrocortisone by using Agilent $\mathrm{C}_{8}$ column $(25 \mathrm{~cm} \times 4.6 \mathrm{~mm}$ i.d., $5 \mu$ ). A simple, selective, rapid, precise and economical reverse phase high performance liquid chromatographic method has been developed for the simultaneous estimation of Hydrocortisone and Acyclovir from pharmaceutical formulation. The method was carried out on a $\mathrm{C}_{8}(25 \mathrm{~cm} \times 4.6 \mathrm{~mm}$ i.d., $5 \mu)$ column with a mobile phase consisting of Methanol: water (adjusted to $\mathrm{pH} 3.0$ using ophosphoric acid) in the ratio of 80:20 v/v. The retention time of Hydricortusone and Acyclovir was $3.50 \mathrm{~min}$ and $6.00 \mathrm{~min}$ respectively with the flow rate of $1 \mathrm{~mL} / \mathrm{min}$. Eluents were detected at $254 \mathrm{~nm}$. The linear regression analysis data for the linearity plot showed good linear relationship with correlation coefficient value for Hydrocortisone and Acyclovir were $\mathrm{R}^{2}=0.9995$ and $\mathrm{R}^{2}=0.9996$ in the concentration range of $10-40 \mu \mathrm{g} . \mathrm{mL}^{-1}, 20-80 \mu \mathrm{g} . \mathrm{mL}^{-1}$ respectively. The relative standard deviation for intra-day precision was lower than $2.0 \%$. The method was validated according to the ICH guidelines. The method was also found to be robust. The developed method was validated in terms of accuracy, precision, linearity, limit of detection, limit of quantification and solution stability.
\end{abstract}

Keywords: RP-HPLC, Hydrocortisone, Acyclovir, Agilent, Mobile Phase, Retention time. 


\section{INTRODUCTION}

Hydrocortisone(HYDRO) is chemically (1S,2R10S,11S,14R,15S,17S)-14,17-dihyroxy-14-(2hydroxyacetyl)-2,15-dimethyl tetracyclo[8.7.0.0^\{2,7\}heptadec-6-en-5-one. HYDRO belongs to Anti-inflammatory Agents. Structure of HYDRO was shown in figure 1[1].

Acyclovir is chemically 2-amino- (hydroxyethoxy)methy6,9-dihydro-3H-purin-6-one. It is used as Antiviral agents .Structure of ACYCLO was shown in figure 2[2].

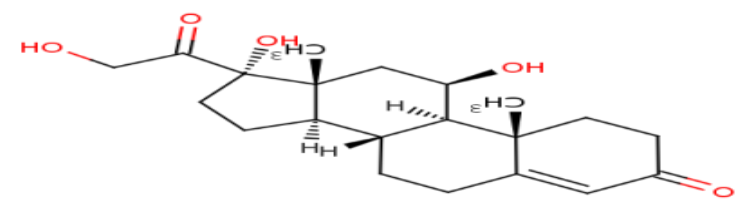

Figure 1: Hydrocortisone

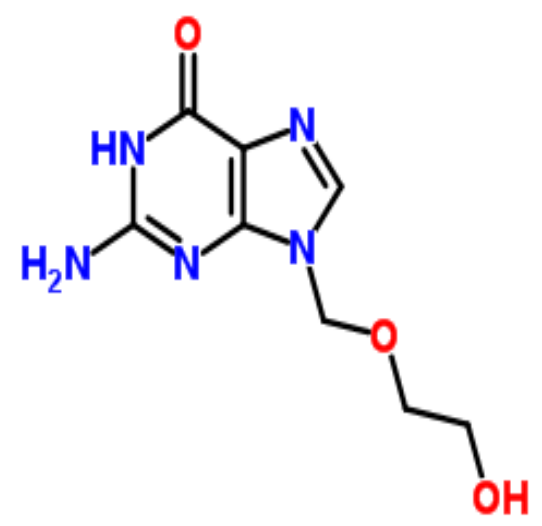

Figure 2: Acyclovir

The review of literature revealed that various analytical methods involving spectrophotometry TLC, HPLC, HPTLC have been reported for HYDRO in single form and in combination with other drugs. Several analytical methods have been reported for ACYCLO in single form and in combination with other drugs including spectrophotometry HPLC, HPTLC, LC - MS. To date, there have been no published reports about the simultaneous estimation of Hydrocortisone and Acyclovir by HPLC in pharmaceutical dosage forms. This present study reports for the first time simultaneous estimation of Hydrocortisone and Acyclovir by HPLC in pharmaceutical dosage form. The proposed method is validated as per ICH guidelines.

Experimental

MATERIALS AND REAGENTS 
Analytically pure HYDRO was kindly provided by Hetero Laboratory, and ACYCLO was provided by Mylan Laboratory, as gift samples. Analytical grade methanol was purchased from Merck \& Co. Glasswares used in each procedure were soaked over night in a mixture of chromic acid and sulphuric acid rinsed thoroughly with double distilled water and dried in hot air oven. Water (HPLC grade) were purchased from Merck, India. Triple distilled water is used for all purpose.

\section{Instrumentation}

HPLC system (Agilent HPLC Model-1100 with Ezchromelite Software) containing $\mathrm{C}_{8}$ (Qualisil BDS, $25 \times 4.6 \mathrm{~mm}, 5 \mu$ ) column with UV- VWD detection. LABINDIA-3000 ${ }^{+}$UV-Visible double beam spectrophotometer with a fixed slit width $1 \mathrm{~nm}$ and $1 \mathrm{~cm}$ matched quartz cells was used for all the spectral measurements.

\section{RESULTS AND DISCUSSION}

\section{Method}

\section{Optimization of the chromatographic conditions}

The mobile phase consisted of methanol and water in ratio Methanol: Water (80:20), pH was adjusted to3.0 with o-phosphoric acid to water. The contents of the mobile phase were filtered before use through a $0.45 \mu$ membrane and degassed for $10 \mathrm{~min}$. The mobile phase was pumped from the solvent reservoir to the column at a flow rate of $1.0 \mathrm{ml} / \mathrm{min}$ and the injection volume was $20 \mu \mathrm{L}$. The column temperature was maintained at ambient temperature. The eluents were monitored at $254 \mathrm{~nm}$. The results of the optimized chromatogram was shown in Figure and Table1. 


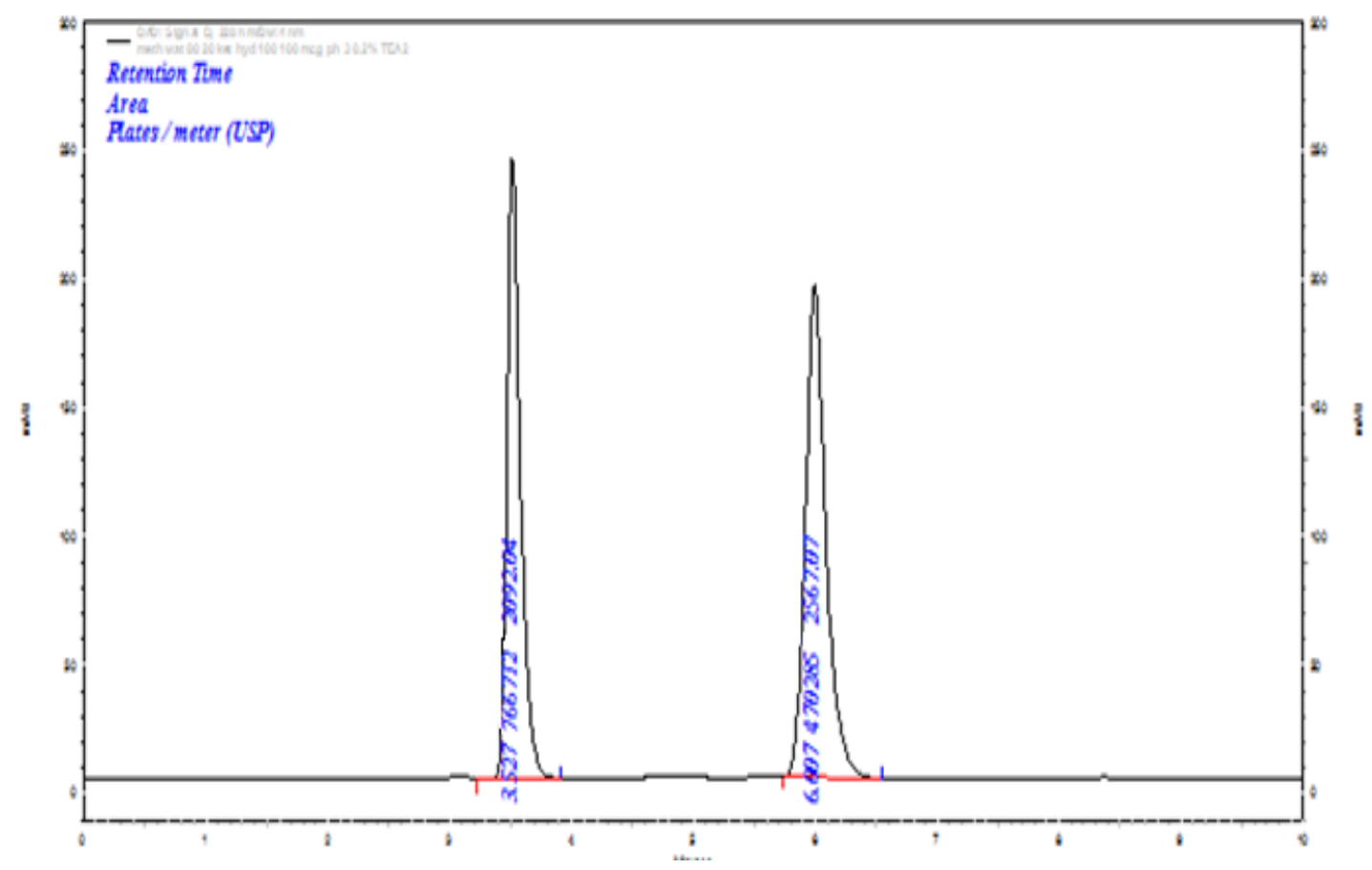

Figure 3: optimized chromatogram of Hydrocortisone and Acyclovir

\section{Preparation of standard stock solutions}

Accurately weighed $10 \mathrm{mg}$ of HYDRO and ACYCLO standard were transferred to separate 10 $\mathrm{ml}$ volumetric flask and dissolved in $10 \mathrm{ml}$ methanol. The flasks were shaken and volume was made up to the mark with methanol to give solutions containing $1000 \mu \mathrm{g} / \mathrm{ml}$ HYDRO and 1000 $\mu \mathrm{g} / \mathrm{ml}$ ACYCLO. From this solution $1 \mathrm{ml}$ was transferred to volumetric flask of $100 \mathrm{ml}$ capacity. Volume was made up to the mark to give a solution containing $100 \mu \mathrm{g} / \mathrm{ml}$ of HYDRO and $100 \mu \mathrm{g} / \mathrm{ml}$ ACYCLO.

\section{Calibration of standards}

The standard calibration curve was constructed for Hydrocortisone and Acyclovir. Different volumes of stock solutions of each were accurately transferred in to $10 \mathrm{~mL}$ volumetric flasks and diluted to mark to yield a concentration range of 10-40 $\mu \mathrm{g} / \mathrm{ml}$ solutions of Hydrocortisone and $20-80 \mu \mathrm{g} / \mathrm{ml}$ solutions of Acyclovir. The calibration line was obtained by plotting the peak area against concentration of drug.

\section{Determination of Hydrocortisone and Acyclovir in their Combined Dosage}

\section{Sample preparation}

A powder quantity equivalent to $10 \mathrm{mg}$ HYDRO and $20 \mathrm{mg}$ ACYCLO was accurately weighed and transferred to volumetric flask of $100 \mathrm{ml}$ capacity, methanol was transferred to this volumetric flask and sonicated for $15 \mathrm{~min}$. The flask was shaken and volume was made up to the 
mark with methanol. The above solution was filtered through Whatmann filter paper $(0.45 \mu)$. From this solution $2 \mathrm{ml}$ was transferred to volumetric flask of $100 \mathrm{ml}$ capacity. Volume was made up to the mark to give a solution containing $10 \mu \mathrm{g} / \mathrm{ml}$ of HYDRO and $20 \mu \mathrm{g} / \mathrm{ml}$ of ACYCLO. The resulting solution was analyzed by proposed method. The quantification was carried out by keeping these values to the straight line equation of calibration curve. The results were shown in Table IV and Figure.

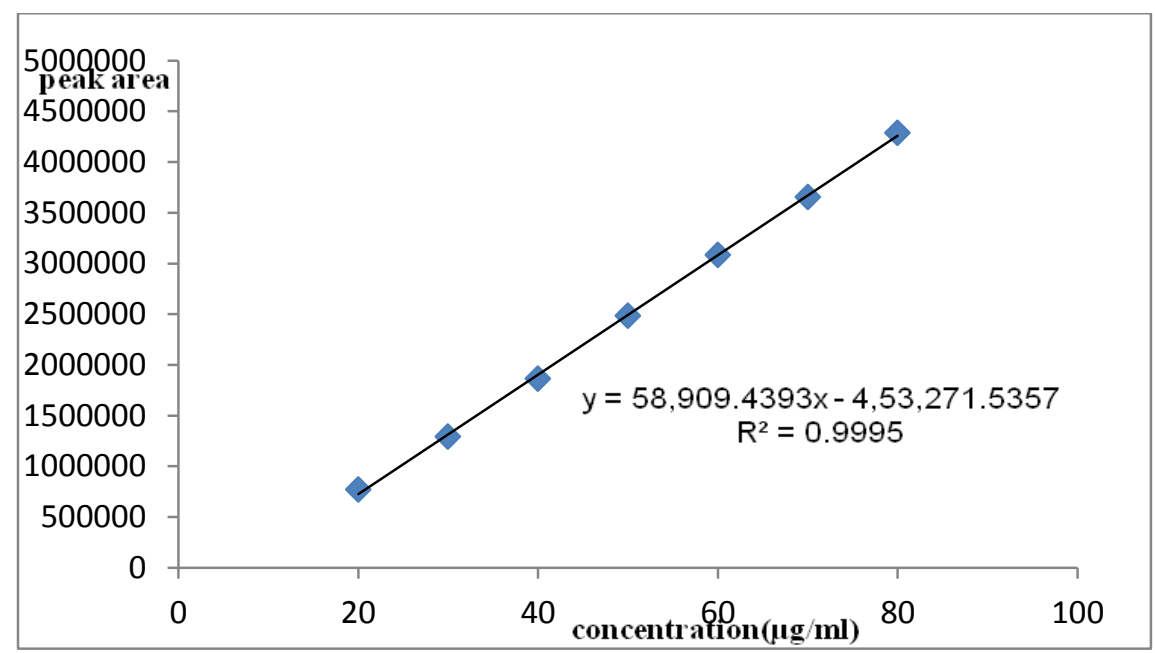

Figure 4: Linearity of Acyclovir at 254nm

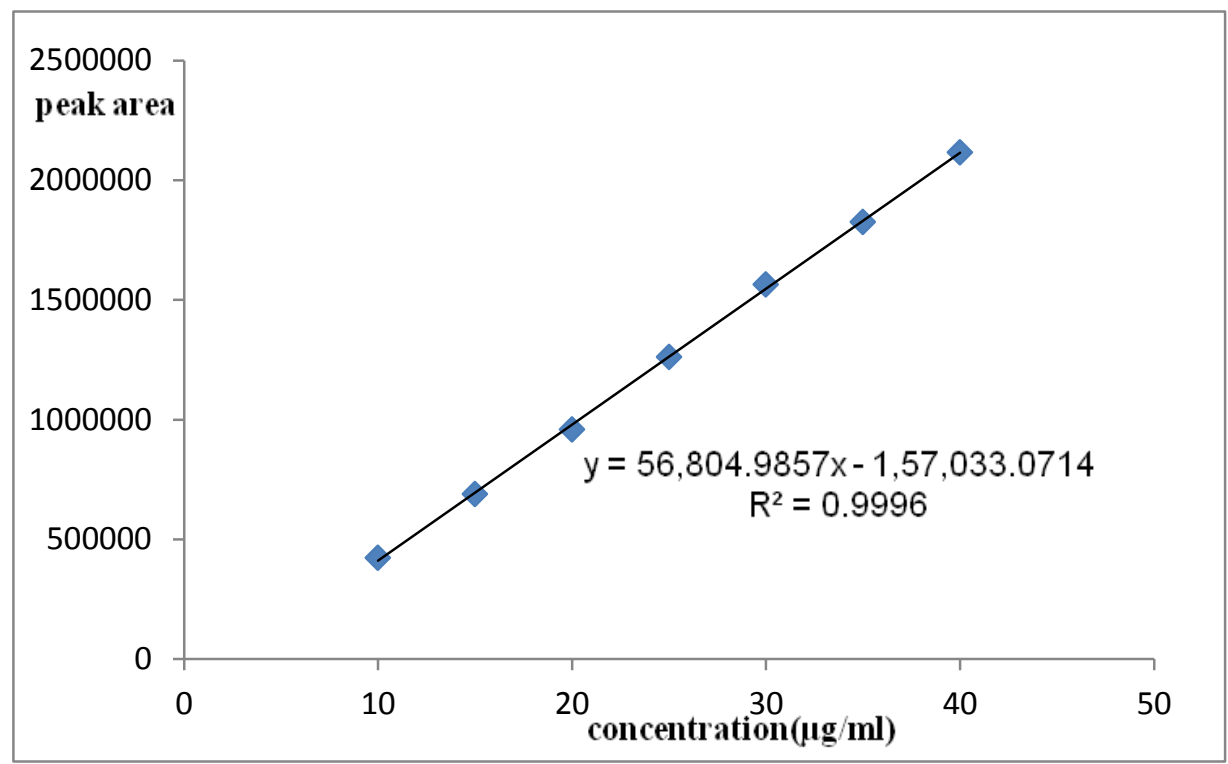

Figure 5: Linearity of Hydrocortisone at 254nm 


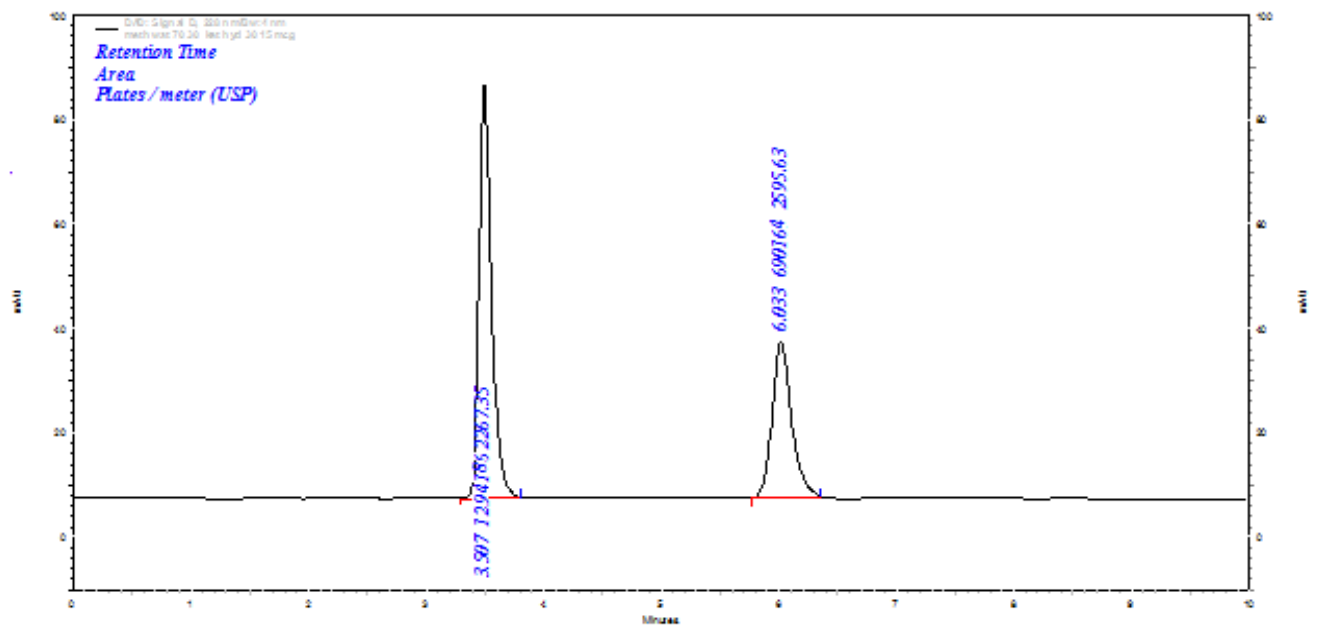

Figure 6: Linearity chromatogram of 15 Hydrocortisone 30 Acyclovir

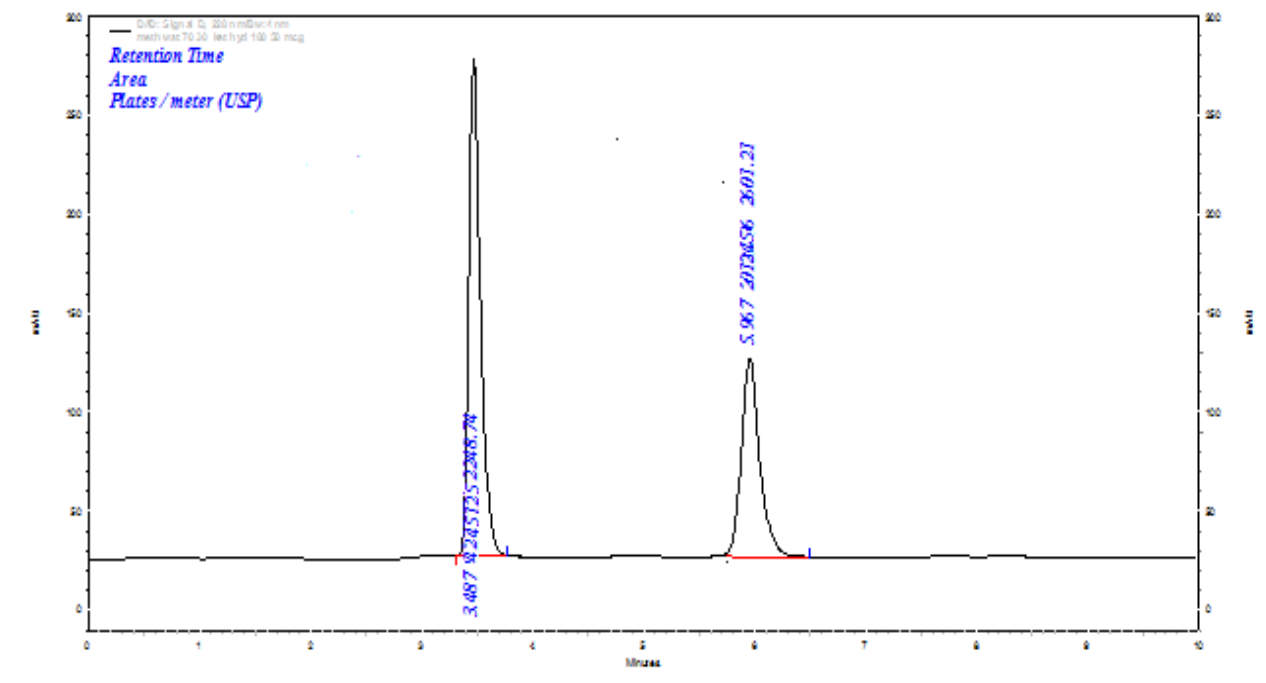

Figure 7: Linearity chromatogram of 40 Hydrocortisone 80 Acyclovir

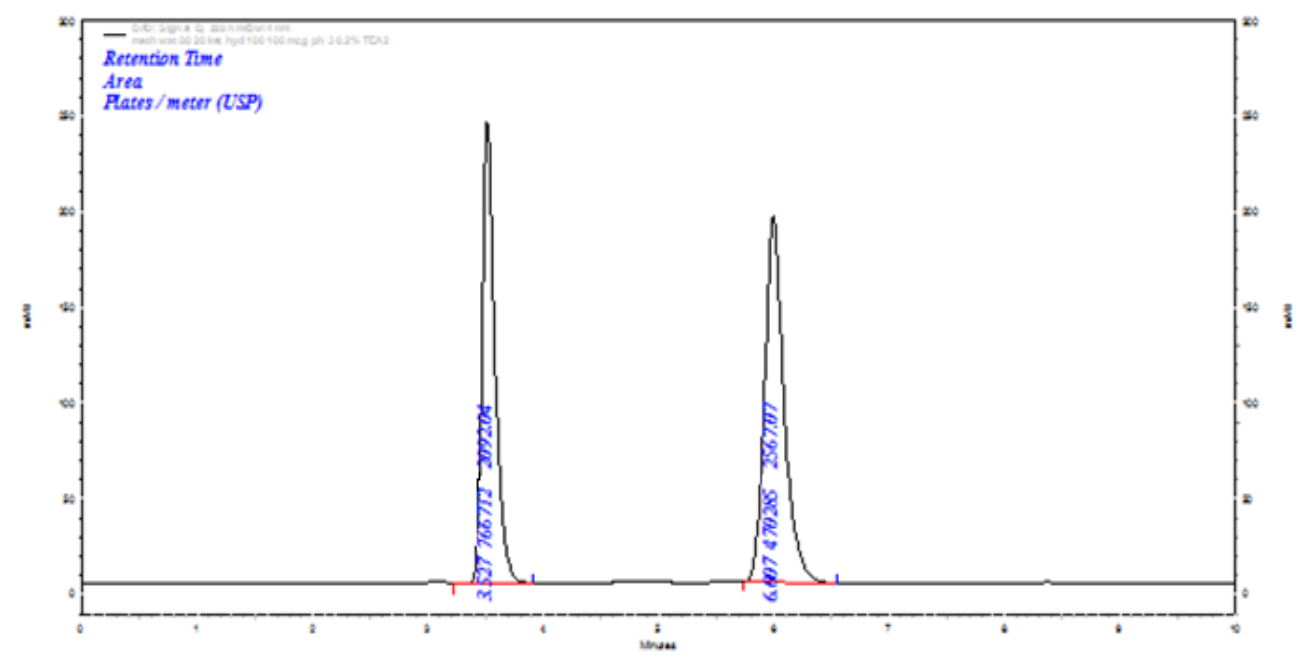

Figure8: Assay chromatogram of 10 Hydrocortisone 50 Acyclovir 


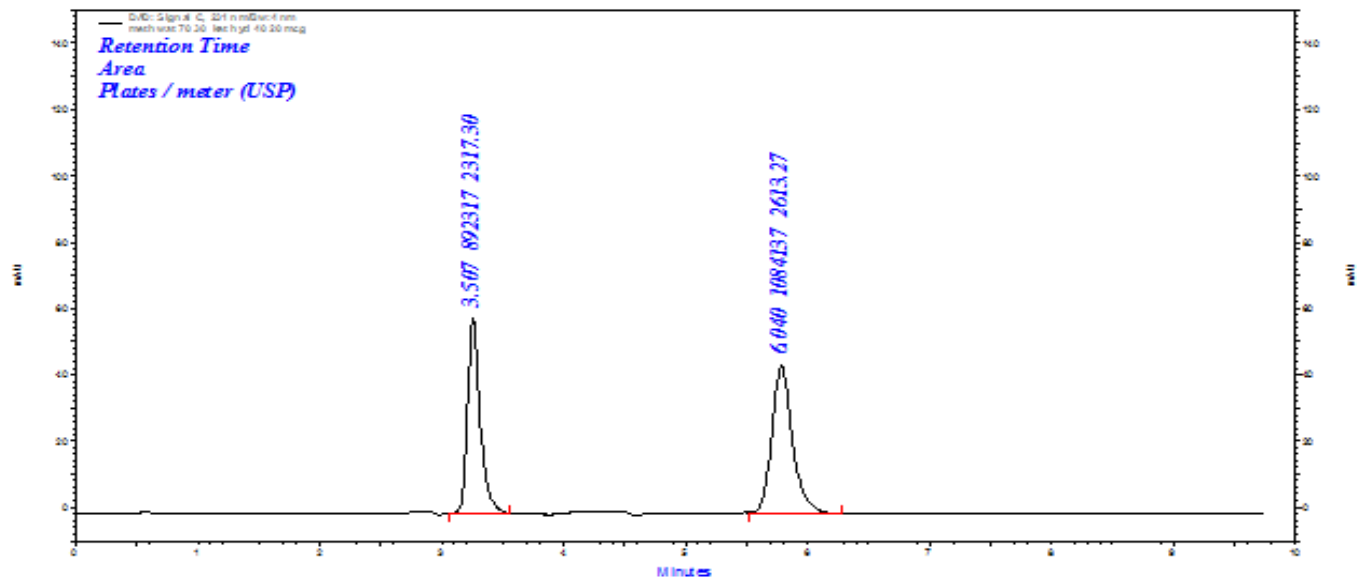

Figure 9: Recovery $80 \%$ chromatogram

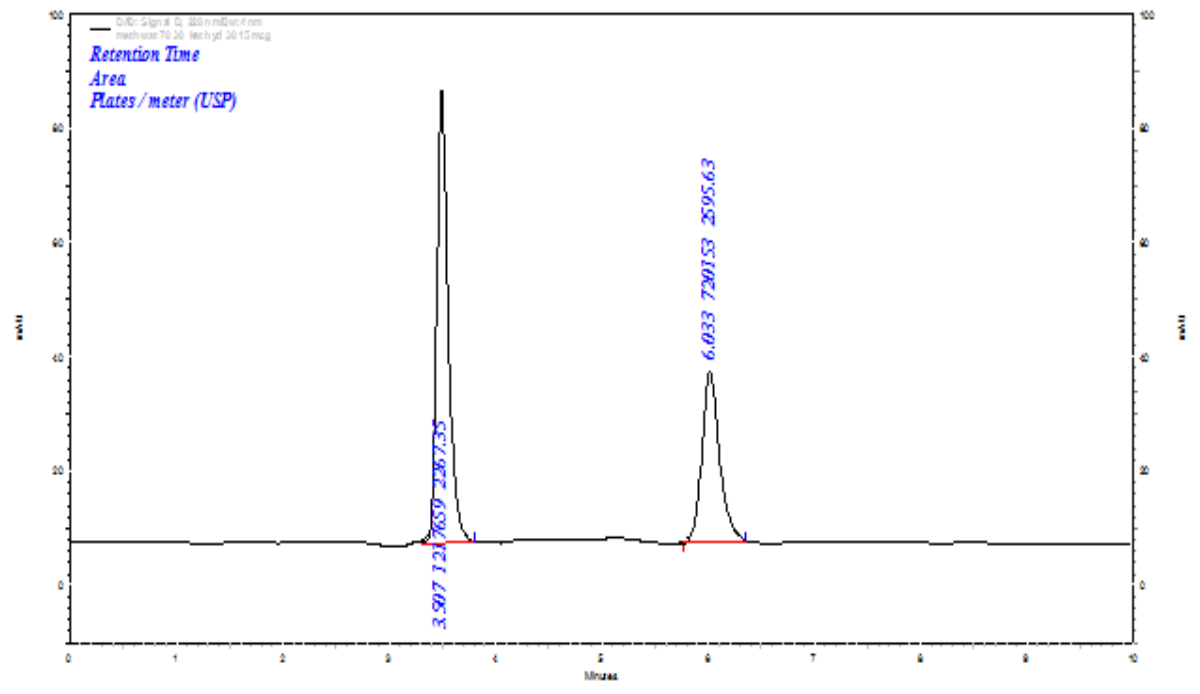

Figure 10: Recovery 100\% chromatogram

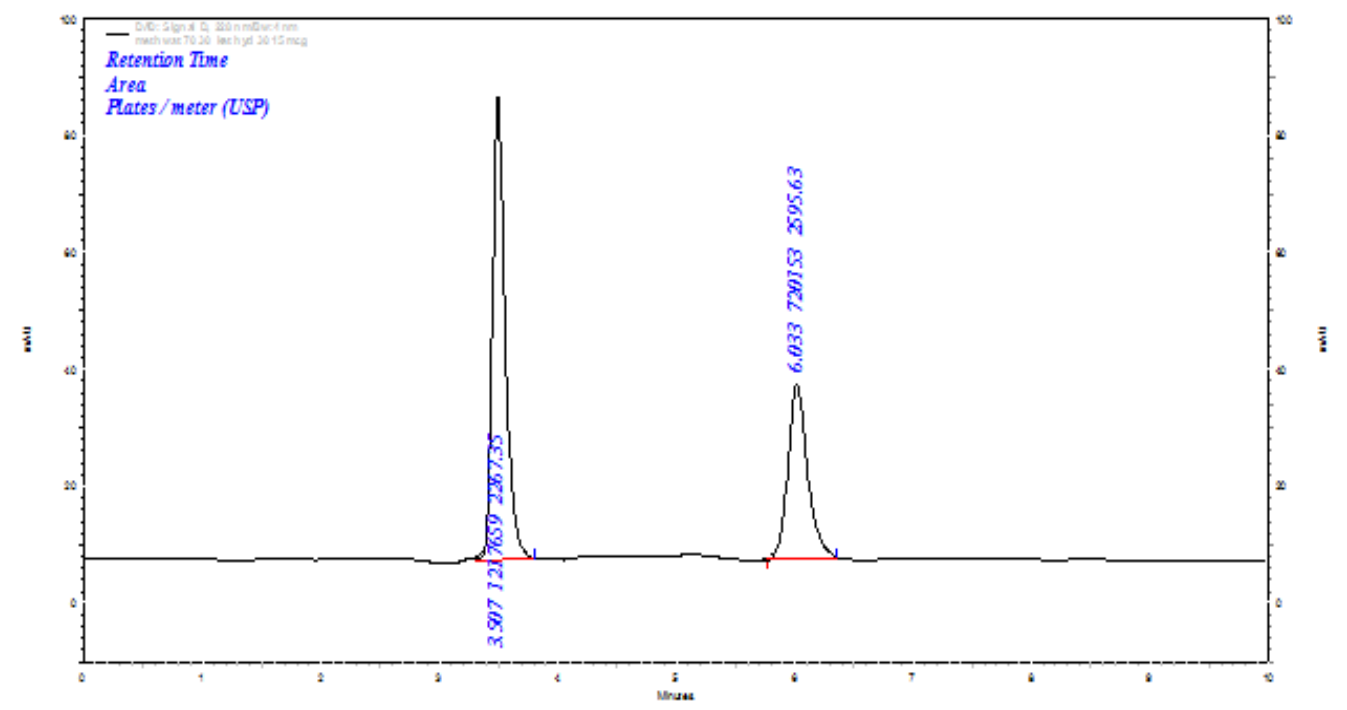

Figure 11: Recovery 120\% chromatogram 


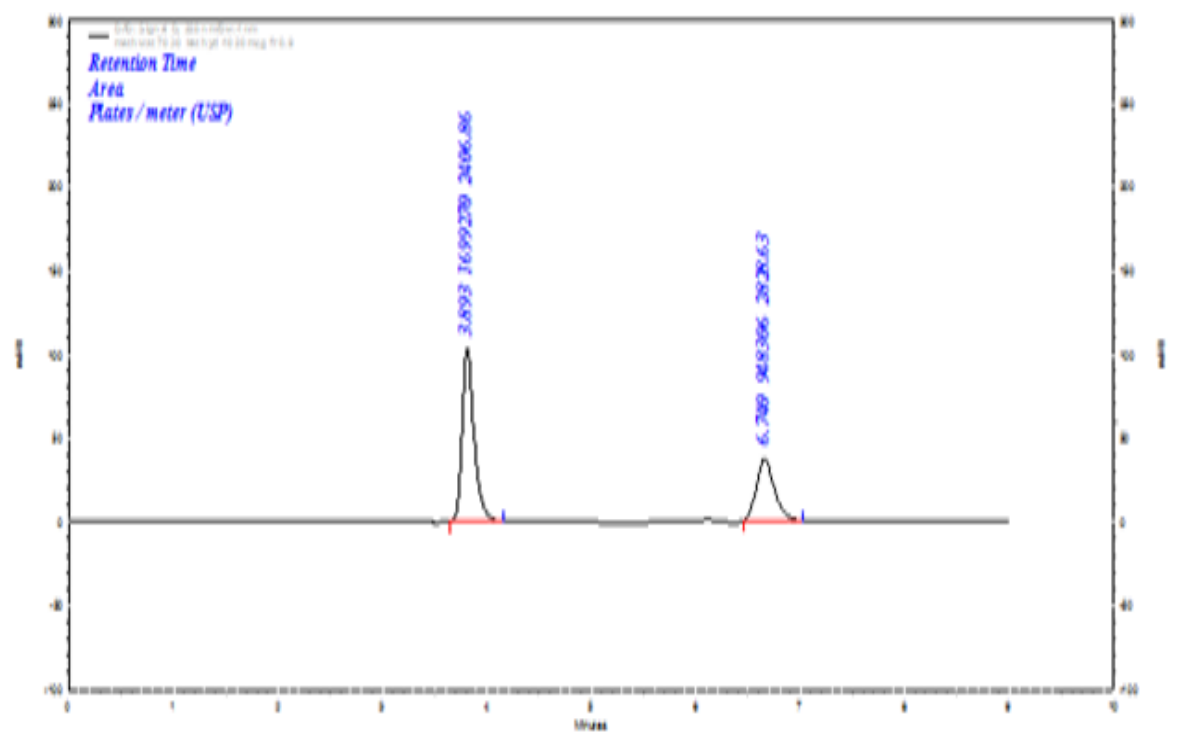

Figure 12: Robust chromatogram of Flow rate $0.9 \mathrm{ml} / \mathrm{min}$

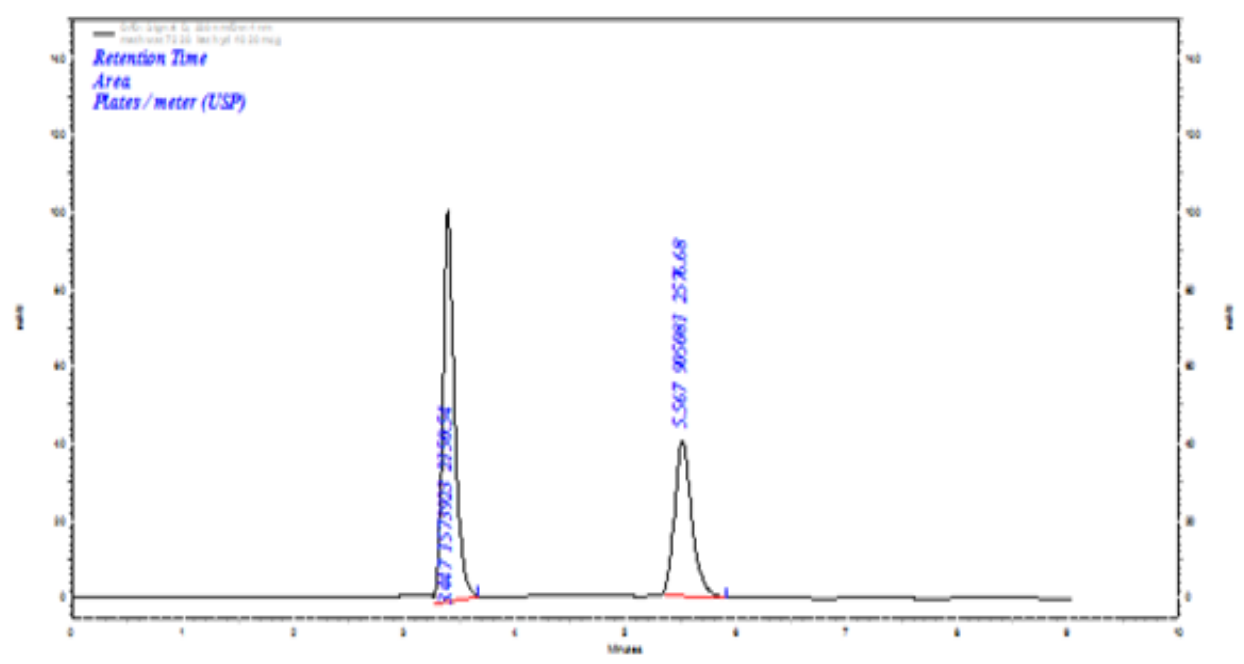

Figure 13: Robust chromatogram of mobile phase composition of Methanol: Water (82:18) Table I: Optimized Chromatographic conditions of Hydrocortisone and Acyclovir on $\mathrm{Cs}_{8}$ Column

\begin{tabular}{llll}
\hline S.No & Parameters & Hydrocortisone & Acyclovir \\
\hline 1 & Mobile Phase Optimized & MeoH $: \mathrm{H}_{2} \mathrm{O}(80: 20)$ & $\mathrm{MeoH}: \mathrm{H}_{2} \mathrm{O}(80: 20)$ \\
2 & Flow Rate $(\mathrm{ml} / \mathrm{min})$ & 1 & 1 \\
3 & Run Time $(\mathrm{min})$ & 10 & 10 \\
4 & ${\text { Column Temperature }{ }^{\mathrm{O}} \mathrm{C}}$ & 23 & 23 \\
5 & Volume of Injection $(\mu \mathrm{l}))$ & 20 & 20 \\
6 & Detection Wavelength $(\mathrm{nm})$ & 221 & 221 \\
7 & Retention time Rt & 3.50 & 6.00 \\
\hline
\end{tabular}




\section{Method validation}

The proposed method has been extensively validated in terms of specificity, linearity, accuracy, precision, limits of detection (LOD) and quantification (LOQ), robustness and reproducibility. The accuracy was expressed in terms of percent recovery of the known amount of the standard drugs added to the known amount of the pharmaceutical dosage forms. The precision (Coefficient of Variation - C.V.) was expressed with respect to the repeatability, intra-day and inter-day variation in the expected drug concentrations. After validation, the developed methods have been applied to pharmaceutical dosage form.

\section{System Suitability Criteria}

It is defined as tests to measure the method that can generate result of acceptable accuracy and precision. The system suitability was carried out after the method development and validation have been completed. The system suitability was assessed by five replicate analyses of the drugs at concentrations of $20 \mu \mathrm{g} \mathrm{mL}^{-1}$ of HYDRO and $10 \mu \mathrm{g} \mathrm{mL} \mathrm{m}^{-1}$ of ACYCLO and for this, parameters like plate number (n), tailing factor, HETP, peak asymmetry of samples were measured, and shown in Table II.

Table II: System suitability parameters for Hydrocortisone and Acyclovir

\begin{tabular}{|c|c|c|c|}
\hline \multirow[t]{2}{*}{ Parameter } & \multicolumn{2}{|c|}{ Values obtained $(n=6)$} & \multirow[t]{2}{*}{ Acceptance Criteria } \\
\hline & Hydrocortisone & Acyclovir & \\
\hline Plate Count & $2092 \pm 62$ & $2567 \pm 87$ & $>2000$ \\
\hline Tailing Factor & $1.100 \pm 0.032$ & $1.097 \pm 0.054$ & $\leq 2.0$ \\
\hline Capacity factor & 0.3 & 1.44 & $<2$ \\
\hline HETP & 0.03789 & 0.03210 & ---- \\
\hline $\mathrm{R}_{\mathrm{t}}$ & 3.50 & 6.00 & ----- \\
\hline
\end{tabular}

\section{Validation parameters}

Method was validated as per ICH (Q2) guidelines with respect to linearity, accuracy, precision, specificity, robustness, limit of detection and limit of quantification.

\section{Specificity}

Commonly used excipients (starch, microcrystalline cellulose and magnesium stearate) were spiked into a pre weighed quantity of drugs. Specificity of the method was shown by quantifying the analyte of interest in the presence of matrix and other components. Blank injections have shown no peaks at retention time of $3.50 \mathrm{~min}$ and $6.00 \mathrm{~min}$, the proposed method was specific for the detection of HYDRO and ACYCLO respectively. The selectivity of the method was performed by injecting the solution after the degradation. The degradants formed during solution 
stability study were well separated from the analyte peak after $20 \mathrm{hrs}$ of sample preparations.

Thus the method can be applied to evaluate the stability of the solution.

\section{Linearity}

Appropriate volume of aliquot from HYDRO and ACYCLO standard stock solution was transferred to volumetric flask of $10 \mathrm{ml}$ capacity. The volume was adjusted to the mark with methanol to give a solutions containing 10-40 $\mu \mathrm{g} / \mathrm{ml}$ HYDRO and 20-80 $\mu \mathrm{g} / \mathrm{ml}$ ACYCLO. The slope, Y-intercept and correlation coefficient were calculated. The regression line relating standard concentrations of drug using regression analysis, the calibration curves were linear in the studied range and equations of the regression analysis were obtained: $\mathrm{Y}=56804.9857 \mathrm{x}+157033.0714 ; \mathrm{R}^{2}=0.9995$ for $\mathrm{HYDRO}$ and $\mathrm{Y}=58909.4393 \mathrm{x}+453271.5356$; $\mathrm{R}^{2}=0.9996$ for ACYCLO respectively. The mean and correlation coefficient of standard curves $(\mathrm{N}=3)$ were calculated. The represented data was shown in below figure 4,5,6,7 and Table III.

Table III: Calibration of Hydrocortisone and Acyclovir

\begin{tabular}{llllll}
\hline $\begin{array}{l}\text { Concentration } \\
\text { of } \\
\text { Hydrocortisone } \\
(\boldsymbol{\mu g} / \mathbf{m l})\end{array}$ & $\begin{array}{l}\text { Peak Area mean } \mathbf{S D}(\mathbf{n = 3}) \text { of } \\
\text { Hydrocortisone }\end{array}$ & $\begin{array}{l}\text { Concentration } \\
\text { of Acyclovir } \\
(\boldsymbol{\mu g} / \mathbf{m l})\end{array}$ & $\begin{array}{l}\text { Peak Area } \\
\text { mean } \pm \\
\text { SD }(\mathbf{n}=3) \text { of } \\
\text { Acyclovir }\end{array}$ & \% RSD & \\
\hline 10 & & 20 & $470286 \pm 1056$ & 0.86 & 0.25 \\
15 & $766712 \pm 6621$ & Hydro & Acyclo \\
20 & $1294165 \pm 21330$ & 30 & $690164 \pm 4385$ & 1.70 & 0.64 \\
25 & $16672234 \pm 10838$ & 40 & $434455 \pm 4677$ & 0.60 & 1.06 \\
30 & $2345254 \pm 11178$ & 50 & $1134567 \pm 51295$ & 0.45 & 0.46 \\
35 & $3145342 \pm 51089$ & 60 & $1456980 \pm 51026$ & 1.67 & 0.36 \\
40 & $3312467 \pm 10021$ & 70 & $1723673 \pm 49568$ & 0.28 & 0.29 \\
\hline
\end{tabular}

Table IV: Assay report of formulation

\begin{tabular}{llllll}
\hline S. No. & Brand name & Content & Peak Area mean \pm S.D & Assay & \%RSD \\
\hline 1 & Xerese & $10 \mu \mathrm{g} / \mathrm{ml}$ Hydrocortisone & $760340 \pm 6610$ & $101.00 \%$ & 1.785 \\
& & $50 \mu \mathrm{g} / \mathrm{ml}$-Acyclovir & $476733 \pm 5687$ & $96.50 \%$ & 1.145 \\
\hline
\end{tabular}

Accuracy

Accuracy was assessed by determination of the recovery of the method by addition of standard drug to the pre-quantified placebo preparation at 3 different concentration levels 80, 100 and 120 $\%$, taking into consideration percentage purity of added bulk drug samples. Each concentration was analyzed 3 times and average recoveries were measured. Results of assay and recovery were presented in the Table V and Figure 9,10,11. 
Table V: Recovery Report of Hydrocortisone and Acyclovir

\begin{tabular}{lllllll}
\hline Drug & $\begin{array}{l}\text { Amount } \\
\text { taken } \\
(\boldsymbol{\mu g} / \mathbf{m l})\end{array}$ & $\begin{array}{l}\text { Recovery } \\
\text { Level }\end{array}$ & $\begin{array}{l}\text { Amount } \\
\text { of Drug } \\
\text { Added }\end{array}$ & $\begin{array}{l}\text { Amount of Drug } \\
\text { Found }(\boldsymbol{\mu g} / \mathbf{m l}) \\
\text { Mean } \pm \text { S.D }\end{array}$ & \% RSD & $\begin{array}{l}\text { \% } \\
\text { Recovery }\end{array}$ \\
\hline Hydro & 10 & $80 \%$ & 8 & $8.06 \pm 0.22$ & 0.225 & 100.05 \\
& & $100 \%$ & 10 & $10.00 \pm 0.18$ & 0.814 & 100.00 \\
& & $120 \%$ & 12 & $12.17 \pm 0.12$ & 0.373 & $101 . .41$ \\
Acyclo & 50 & $80 \%$ & 16 & $46.15 \pm 0.168$ & 0.234 & 100.93 \\
& & $100 \%$ & 20 & $50.22 \pm 0.46$ & 0.902 & 101.00 \\
& & $120 \%$ & 24 & $53.96 \pm 0.24$ & 0.262 & 99.83 \\
\hline
\end{tabular}

\section{Precision}

The repeatability was evaluated by assaying 6 times of sample solution prepared for assay determination. The intraday and interday precision study of HYDRO and ACYCLO was carried out by estimating different concentrations of HYDRO (10, 25, $40 \mu \mathrm{g} / \mathrm{ml})$ and ACYCLO (20, 50, $80 \mu \mathrm{g} / \mathrm{ml}$ ), 3 times on the same day and on 3 different days (first, second, third) and the results are reported in terms of C.V. The results are shown in Table VI.

\section{Table VI: Precision}

\section{Intra-day and Inter-day Precision}

Intra-day Precision Data for Hydrocortisone and Acyclovir

\begin{tabular}{lllllll}
\hline S. No & $\begin{array}{l}\text { Conc. } \\
(\boldsymbol{\mu g} / \mathbf{m l}) \\
\text { of Hydro }\end{array}$ & $\begin{array}{l}\text { Peak Area } \\
\text { mean } \pm \text { S.D }(\mathbf{n}=3)\end{array}$ & $\begin{array}{l}\text { Conc. } \\
\text { of Hydro }\end{array}$ & $\begin{array}{l}\text { Peak Area }) \\
\text { of Acyclo } \\
\text { mean } \pm \text { S.D }(\mathbf{n = 3}) \\
\text { of Acyclo }\end{array}$ & $\begin{array}{l}\text { \% RSD } \\
\text { Hydro }\end{array}$ & Acyclo \\
\hline 1 & 10 & $754892 \pm 6523$ & 20 & $443468 \pm 1034$ & 0.86 & 0.25 \\
2 & 25 & $2345254 \pm 11032$ & 50 & $1261647 \pm 51340$ & 0.47 & 0.30 \\
3 & 40 & $4234568 \pm 11257$ & 80 & $2015712 \pm 17045$ & 0.29 & 0.80 \\
& & & Avg. of \%RSD & 1.62 & 1.35 \\
\hline
\end{tabular}

Inter-day Precision Data of Hydrocortisone and Acyclovir

\begin{tabular}{|c|c|c|c|c|c|c|}
\hline S. No & $\begin{array}{l}\text { Conc. } \\
(\mu \mathrm{g} / \mathrm{ml}) \\
\text { of Hydro }\end{array}$ & $\begin{array}{l}\text { Peak Area } \\
\text { mean } \pm \text { S.D }(n=3) \\
\text { of Hydro }\end{array}$ & $\begin{array}{l}\text { Conc. } \\
(\mu \mathrm{g} / \mathrm{ml}) \\
\text { of Acyclo }\end{array}$ & $\begin{array}{l}\text { Peak Area } \\
\text { mean } \pm S . D(n=3) \\
\text { of Acyclo }\end{array}$ & $\begin{array}{l}\text { \% RSD } \\
\text { Hydro }\end{array}$ & Acyclo \\
\hline 1 & 10 & $758345 \pm 6530$ & 20 & $4424453 \pm 1123$ & 0.90 & 0.30 \\
\hline 2 & 20 & $2346537 \pm 11212$ & 50 & $1234567 \pm 51433$ & 0.50 & 0.89 \\
\hline 3 & 80 & $4222567 \pm 11421$ & 80 & $2014589 \pm 17312$ & 0.35 & 0.30 \\
\hline \multicolumn{5}{|c|}{ Avg. of \% RSD } & 1.75 & 1.49 \\
\hline
\end{tabular}

\section{Robustness}

The robustness of the method was evaluated by analyzing the system suitability standards and evaluating system suitability parameter data after varying the HPLC pump flow rate $( \pm 0.1 \mathrm{ml})$ and organic solvent content $( \pm 2 \mathrm{ml})$ and $\mathrm{pH}( \pm 0.2)$. None of the alterations caused a significant change in peak area R.S.D (\%), USP tailing factor and theoretical plates. Although the changes 
in retention times were more significant, and quantification was still possible. Results of robustness studies are shown in Table VII and Figure 12,13.

Table VII: Robustness studies of Hydrocortisone and Acyclovir

\begin{tabular}{|c|c|c|c|c|c|c|}
\hline \multirow[t]{2}{*}{ S. No } & \multirow[t]{2}{*}{ Parameter } & \multirow[t]{2}{*}{ Modification } & \multicolumn{2}{|c|}{ Retention time } & \multicolumn{2}{|c|}{ Tailing Factor } \\
\hline & & & Hydro & Acyclo & Hydro & Acyclo \\
\hline \multirow[t]{3}{*}{1} & \multirow[t]{3}{*}{ Flow rate } & $0.9 \mathrm{ml} / \mathrm{min}$ & $3.55 \mathrm{~min}$ & $6.76 \mathrm{~min}$ & 1.152 & 1.140 \\
\hline & & $1.0 \mathrm{ml} / \mathrm{min}$ & $3.50 \mathrm{~min}$ & $6.00 \mathrm{~min}$ & 1.100 & 1.097 \\
\hline & & $1.1 \mathrm{ml} / \mathrm{min}$ & $2.88 \mathrm{~min}$ & $5.50 \mathrm{~min}$ & 1.165 & 1.393 \\
\hline \multirow[t]{3}{*}{2} & Mobile phase & $73: 27$ & $3.19 \mathrm{~min}$ & $6.75 \mathrm{~min}$ & 1.152 & 1.146 \\
\hline & Composition & $80: 20$ & $3.50 \mathrm{~min}$ & $6.00 \mathrm{~min}$ & 1.100 & 1.097 \\
\hline & (MeOH:H2O) & $82: 18$ & $3.10 \mathrm{~min}$ & $5.58 \mathrm{~min}$ & 1.167 & 1.314 \\
\hline \multirow[t]{2}{*}{3} & $\mathrm{pH}$ & 3.0 & $3.50 \mathrm{~min}$ & $6.00 \mathrm{~min}$ & 1.100 & 1.097 \\
\hline & & 3.2 & $3.180 \mathrm{~min}$ & $6.12 \mathrm{~min}$ & 1.149 & 1.110 \\
\hline \multirow[t]{3}{*}{4} & Wavelength & 251 & $3.18 \mathrm{~min}$ & $6.12 \mathrm{~min}$ & 1.139 & 1.107 \\
\hline & & 254 & $3.50 \mathrm{~min}$ & $6.00 \mathrm{~min}$ & 1.100 & 1.097 \\
\hline & & 256 & $3.18 \mathrm{~min}$ & $6.12 \mathrm{~min}$ & 1.164 & 1.104 \\
\hline
\end{tabular}

\section{$L O D$ and $L O Q$}

LOD and LOQ were calculated from the formula $3.3 \times(\sigma / \mathrm{S})$ and $10 \times(\sigma / \mathrm{S})$, respectively where, $\sigma$ is standard deviation of intercept and S is the mean of slope. The LOD and LOQ can also be determined by $\mathrm{S} / \mathrm{N}$. The value for LOD should be 3-5 whilst for LOQ 10-15. The results are presented in Table VIII.

Table VIII: LOD and LOQ data

\begin{tabular}{llll}
\hline S.No. & Parameter & Hydrocortisone & Acyclovir \\
\hline 1 & LOD & $1.294 \mu \mathrm{g} / \mathrm{ml}$ & $0.241 \mu \mathrm{g} / \mathrm{ml}$ \\
2 & LOQ & $3.922 \mu \mathrm{g} / \mathrm{ml}$ & $0.733 \mu \mathrm{g} / \mathrm{ml}$ \\
\hline
\end{tabular}

\section{Solution stability and Mobile phase stability}

The stability of HYDRO and ACYCLO in solution was determined by leaving test solutions of the sample and reference standard in tightly capped volumetric flasks at room temperature for 3 days during which they were assayed at $12 \mathrm{~h}$ intervals. Stability of mobile phase was determined by analysis of freshly prepared sample solutions at $12 \mathrm{~h}$ intervals for $48 \mathrm{~h}$ and comparing the results with those obtained from freshly prepared reference standard solutions. The mobile phase was prepared at the beginning of the study period and not changed during the experiment. The $\%$ assay of the results was calculated for both the mobile phase and solution-stability experiments.

\section{CONCLUSION}

The present study represents an accurate, precise and specific HPLC method for routine analysis of Hydrocortisone and Acyclovir combination in Cream(tablet) dosage form. In addition to 
assay it may be used to detect related substance or other impurities which are formed during storage conditions and the analyte of interest could be estimated without any interferences. The use of $\mathrm{C}_{8}$ column in the present work has shown better elution of analytes with good resolution, improved plate count, capacity factor, reduced tailing. So the $\mathrm{C}_{18}$ column can be used to achieve high specificity in shorter time of analysis Hydrocortisone to Acyclovir in tablet as per ICH Q2 (R2) guidelines.

The developed UV-spectrophotometric method for simultaneous determination of Hydrocortisone and Acyclovir in combined pharmaceutical dosage form is simple and reliable. From the study of validation parameters namely accuracy, precision (SD and RSD), (interday, intraday and different analyst), specificity, linearity and range, it was observed that the method is specific, accurate, precise and reproducible. Hence the method can be employed for routine analysis of dosage form.

\section{REFERENCES}

1. Hisham, E.; Journal of. Pharmaceutical and Biomedical Analysis, (1998); 17, 1267.

2. Simoncic, Z., Roskar, R., Gartner, A., Kogej, K., and Kmetec, V.; International Journal of Pharmaceutics, (2008); 356, 200.

3. Medenica, M., Ivanovic, D., Maskovic, M., Jancic, B., and Malenovic A.; Journal of Pharmaceutical and Biomedical Analysis, (2007); 44, 1087.

4. Validation of Analytical Procedures: Text and Methodology (Q2B), ICH Harmonized Tripartite Guideline.

5. General Chapter 1225, Validation of compendial methods, United States Pharmacopeia 30, National Formulary 25, Rockville, Md., USA, The United States Pharmacopoeia Convention ,Inc., (2007).

6. Stability Testing of New Drug Substances and Products (Q1A (R2)), ICH Harmonized Tripartite Guideline.

7. Nash, R.A., Wachter, A.H.; Pharmaceutical process validation, 3rd volume 129, pp.507523. Grace S. N. Lau, J. A. J. H. Critchley ,Ankit Patel, Jaimin Patel, Amit Shah.; Development and validation of spectrophotometric method for Simultaneous estimation of Hydrocortisone and Ketoconazole in Tablet dosage form, International Journal of Pharmacy and Pharmaceutical Sciences,(2012); 56, 198.

8. Anantha Kumar D.; Sujan D.P.; Vijayasree V.; Seshagiri rao J.V.L.N. Development and validation of dual wavelength spectrophotometric method for simultaneous estimation of 
Hydrocrtisone and Ketoconazole in their combined dosage form, E.J.Chem. 2009; 6: 541-544.

9. ICH-Q2A. Text on Validation of Analytical Procedures, March 1995.

10. Ofosua Adi-dako.;Samuel oppong Bekoe.;Kwabena ofori-Kwakye.;Novel HPLC Analysis of Hydrocortisone in Conventional and Controlled -Release Pharmaceutical Preparations, Pharmaceutics,(2017),9495732,8.

11. A. Yadagiri naga manikanta. Analytical Method development and validation of Hydrocortisone and Miconazole Simultaneous in Topical dosage form by RPHPLC,(2015), Volume 4,Issue 8,2063-2080.

12. A. Smidovnik, Alenka golc wondra,Mirko prosek. Determination of Acyclovir in by High performance liquid chromatography with UV-Detection ,method development and method validation(2015)1240200908.

13. www.google.com 